\title{
Knowledge of Health Consequences of Psychoactive Substance Use among Senior Secondary School Students
}

\author{
Winifred A. Ojieabu ${ }^{{ }^{1}}$, Shakirat I. Bello ${ }^{2}$, J ohn E. Arute ${ }^{3}$, Adebukola A. Tijani ${ }^{1}$, \\ Lionel 0. Okunye ${ }^{4}$, Sule A. Saka ${ }^{1}$, Christabel E. Ojieabu ${ }^{5}$, Philip F. Uzor ${ }^{6}$, \\ Mark O. Akpotu ${ }^{4}$ and Uchenna I.H. Eze ${ }^{1}$
}
${ }^{1}$ Department of Clinical Pharmacy and Biopharmacy, Faculty of Pharmacy, Olabisi Onabanjo University Sagamu Campus, Sagamu, Ogun State, Nigeria
${ }^{2}$ Department of Clinical Pharmacy and Pharmacy Practice, Faculty of Pharmaceutical Sciences University of Ilorin, Ilorin, Nigeria
${ }^{3}$ Department of Clinical Pharmacy and Pharmacy Administration, Faculty of Pharmacy Delta State University, Abraka, Nigeria
${ }^{4}$ Department of Pharmaceutical Microbiology, Faculty of Pharmacy, Olabisi Onabanjo University Sagamu Campus, Sagamu, Ogun State, Nigeria
${ }^{5}$ Obafemi Awolowo College of Health Science, Olabisi Onabanjo University, Sagamu Campus Sagamu, Ogun State, Nigeria
${ }^{6}$ Department of Pharmaceutical and Medicinal Chemistry, Faculty of Pharmaceutical Sciences University of Nigeria, Nsukka, Nigeria

(Received: June 07, 2020; Accepted: December 01, 2020; Published (web): December 01, 2020)

\begin{abstract}
The rate of psychoactive substance (PAS) use in the adolescent group is increasing around the world. Drug abuse has a negative impact on students' education especially that of secondary school students. This study aimed to assess the prevalence of psychoactive substance use and knowledge of the health consequences among secondary school students in Ogun State, Nigeria. A cross-sectional study was carried out among 528 consenting students selected using random sampling method. Data obtained using a validated modified World Health Organization's guidelines questionnaire were analyzed with SPSS $20, \mathrm{p}$-Value $\leq 0.05$ was considered significant. Majority (78.8\%) were within the age group 15-18 years, males were 61.4\%. Alcohol (95.0\%) ranked first of all the substances been consumed among the current PAS users. Age was highly significantly associated with PAS use. Average knowledge of health consequences of PAS use was $11.5 \%$. There is need for continuous health educational intervention to boost the respondents' knowledge about health consequences of uses of psychoactive substances.
\end{abstract}

Key words: Psychoactive substance, Students, Health consequences, Knowledge

\section{INTRODUCTION}

American Psychiatric Association DSM-IV ${ }^{1}$ describes psychoactive substance (PAS) use as the self-administration of un-prescribed substance for the purpose of effecting mood and behavioral alterations irrespective of the known likely untoward effects. About 7.0\% of the age group 15-64 years of the total world population had been involved in illicit drug

Correspondence to: Winifred A. Ojieabu

E-mail: natbelpharmacy@yahoo.com;

Phone Number: +2348037126245

Dhaka Univ. J. Pharm. Sci. 19(2): 199-205, 2020 (December) DOI: https://doi.org/10.3329/dujps.v19i2.50637 use. $^{2}$ The rate of PAS use in the adolescent group is high in the developed countries e.g. United States of America and United Kingdom. ${ }^{3}$ The same trend is also found in Africa. ${ }^{4}$ In 2012, a mortality rate of 40 from drug-related deaths per million in age groups between 15-64 years was reported in World Drug Report. $^{2} \quad$ Increased use of PAS in developing countries such as Nigeria is no longer new ${ }^{5}$ and adolescents are at the epicenter of it. ${ }^{6}$

Drug abuse has a negative impact on students' education especially at secondary school level. Prevailing consequences emanating from drug abuse among adolescents, youths and adults include 
academic problems, health problems, stigmatization, family and social-economic problems and crimes among others. ${ }^{2}$ This study was therefore aimed to assess the prevalence of PAS use and knowledge of the health consequences among secondary school students in Sagamu town, Ogun State, Nigeria.

\section{MATERIALS AND METHODS}

Study population. This was a cross-sectional study, carried out among 528 consenting students selected using random sampling method from three senior secondary schools within Sagamu city. Sagamu is one of the local government headquarters in Ogun state, Nigeria. The Principals of the three senior secondary schools were contacted prior to the administration of the pretested questionnaire, during which the intended purpose was made known to them. Verbal consent was given by the Principals and the students before we conducted the study. The sample questionnaire has been shown in Table 1 .

Table 1. Sample questionnaire.

Section A: Socio- Demographics

1. $\quad$ Age (at last birthday)----------------years

2. Sex: male() female()

3 Class level

4. Parental marital status: Single() Married() Divorced/Separated()

5. Family type: Monogamous() Polygamous()

6. Religion: Muslim() Christian() traditional() other(please specify)---------------

7. Do you have any health challenges? Yes() No()

8. Have you ever known of psychoactive substance (PAS)?: Yes() No()

Section B: Psychoative substance use and who introduced you to it?

1. Have you ever used any psychoactive substance (PAS)? Yes () No()

2. Are you still using any? Yes() No()

3. Do any of your family members use PAS? Father () mother() both parents() siblings() other family members() friends/peers() our driver() gateman()

Section C: Prevalence of Psychoative substance use among students

1. What types of psychoactive substance have you ever used? Tobacco () marijuana() tramadol () caffeine () heroin() codeine in syrup() cocaine() alcohol() analgesic () none () others (please specify)

2. Please tick if you are currently using any or all these: Tobacco () marijuana() tramadol () caffeine () heroin() codeine in syrup() cocaine() alcohol() analgesic () none () others (please specify)

Section D: Knowledge of health consequences of psychoactive substance use These groups of drugs can cause the following health problems. Please tick one right answers

1. 1. Depressants (e.g. Alcohol, Tranquilizer) can cause: Depression, anxiety disorders, psychiatric issues suicide risk. Damage to brain, lung and liver resulting in dysfunction. True() False() Don't know()

2. 2. Stimulants (e.g. Cocaine, caffeine, Nicotine) can cause: Bronchial infections, lung cancer Cause convulsion, heart malfunction, stroke, seizure and eventual death. True() False() Don't know()

3. 3. Narcotics (e.g. Heroin, codeine, tramadol) can cause: Mental deterioration, brain damage, result in hepatitis and death in case of overuse. True() False() Don't know()

4. 4. Cannabis (e.g. Marijuana) can cause: Lowered blood pressure, and impairment of short-term memory. Result in brain, heart and lung damage leading to improper function. True() False() Don't know()

Sample size estimate and sampling technique. The minimum sample size was determined using fisher's formula $\mathrm{n}=\mathrm{Z}^{2} \mathrm{pq} \div(\mathrm{d})=\left(1.96^{2} \times 0.05 \times\right.$ $0.05) / 0.05=384$ but this figure was eventually increased to 550 .
Data collection. We employed a validated World Health Organization's guidelines questionnaire for students and substances for survey data collection. The anonymous self-administered questionnaire included the following sections: socio 
demographics, PAS use, introducer of PAS, prevalence of PAS uses among the respondents and knowledge of health consequences of PAS abuse. The students were being assured of confidentiality of their information and were briefed on the purpose of the study before distribution of the questionnaire.

Table 2. Socio demographics of respondents $(\mathrm{N}=528)$.

\begin{tabular}{|c|c|c|c|}
\hline $\begin{array}{l}\text { Variables of } \\
\text { respondents }\end{array}$ & $\begin{array}{l}\text { Frequency } \\
(\mathrm{N})\end{array}$ & $\begin{array}{c}\text { Percentage } \\
(\%)\end{array}$ & p-Value \\
\hline \multicolumn{4}{|l|}{ Age } \\
\hline$<15$ & 67 & 12.7 & $<0.000^{*}$ \\
\hline $15-18$ & 416 & 78.8 & \\
\hline$>18$ & 45 & 8.5 & \\
\hline \multicolumn{4}{|l|}{ Sex } \\
\hline Male & 324 & 61.4 & $<0.000^{*}$ \\
\hline Female & 204 & 38.6 & \\
\hline \multicolumn{4}{|l|}{ Class level } \\
\hline SS1 & 101 & 19.1 & $<0.000^{*}$ \\
\hline SS2 & 240 & 45.5 & \\
\hline SS3 & 187 & 35.4 & \\
\hline \multicolumn{4}{|l|}{$\begin{array}{l}\text { Parent marital } \\
\text { status }\end{array}$} \\
\hline Single & 173 & 32.8 & $<0.000^{*}$ \\
\hline Married & 329 & 62.3 & \\
\hline Divorced/Separated & 26 & 4.9 & \\
\hline \multicolumn{4}{|l|}{ Family type } \\
\hline Monogamous & 432 & 81.8 & $<0.000 *$ \\
\hline Polygamous & 96 & 18.2 & \\
\hline \multicolumn{4}{|l|}{ Religion } \\
\hline Muslim & 167 & 31.6 & $<0.000 *$ \\
\hline Christian & 359 & 68.0 & \\
\hline Traditional & 2 & 0.4 & \\
\hline \multicolumn{4}{|l|}{$\begin{array}{l}\text { Have health } \\
\text { challenges }\end{array}$} \\
\hline Yes & 61 & 11.6 & $<0.000 *$ \\
\hline No & 467 & 88.4 & \\
\hline \multicolumn{4}{|l|}{$\begin{array}{l}\text { Ever known about } \\
\text { psychoactive } \\
\text { substances (PAS) }\end{array}$} \\
\hline Yes & 241 & 45.6 & 0.110 \\
\hline No & 287 & 54.4 & \\
\hline
\end{tabular}

Data analysis. Data were checked before being entered into Microsoft Excel for sorting. Further analysis was performed with Statistical Package for Social Sciences (SPSS) software, version 20,
(Chicago, Illinois), and using descriptive and comparative analyses. Comparison of proportions was carried out with Chi-square and Fisher's exact tests. $\mathrm{P} \leq 0.05$ was considered statistically significant.

Ethical consideration. The study protocol was submitted to the Ethical Review Committee of Federal Medical Centre, Abeokuta, Ogun State, Nigeria. Approval was granted for this study by the committee (Approval No: FMCA/243/HREC/ 03/2018/12).

\section{RESULTS}

Majority (78.8\%) of the respondents were within the age group 15-18 years. The respondents had the following features: males (61.4\%), SS2 (45.5\%), married parents (62.3\%), monogamous family (81.8\%), Christianity (68.0\%) and those who had known PAS (54.4\%) use history (Table 2). The number of the respondents that ever used PAS was 291 (55.1\%). Siblings (24\%) and friends/peers $(38.4 \%)$ of current users were PAS users. Those who introduced the current users were mainly friends/peers (49.8\%) (Table 3). Alcohol (95.0\%) ranked first of all the substances being consumed among the current PAS users, followed by codeine in syrup $(85.8 \%)$ and caffeine $(80.1 \%)$. The least used PAS were marijuana $(9.0 \% / 3.6 \%)$ and cocaine $(16.1 \% / 6.4 \%)$ in both current and whole population respectively (Table 4). All the socio-demographic variables of the respondents, except class level and religion were significantly associated with PAS use ( $\mathrm{p} \leq 0.05)$. (Table 5). All the respondents across board did not have enough knowledge of the health consequences of PAS abuse as demonstrated by their responses in relation to the different classes of PAS they used $(\mathrm{p} \leq 0.05)$. The average knowledge of the health consequences among the respondents was $11.5 \%$ (Table 6).

\section{DISCUSSION}

Out of 550 copies of the questionnaire administered to the students, 528 were correctly filled, giving us $96.0 \%$ response rate. Age range 1518 years $(78.8 \%)$ was found to be significantly higher 
than the others in this study and it is the age range mostly found in Nigerian secondary schools. This is also the adolescent age which conforms to earlier findings. ${ }^{7,8}$ This age group has also been said to be the most susceptible group for experimentation and prone to PAS use. According to a previous study ${ }^{9}$, adolescence period involves both physical and psychological changes coupled with the urge to try out new things including drug use and sexual affairs while undermining their grievous outcomes.

As pertaining to gender presentation, we found males $(61.4 \%)$ to be significantly more than females and this is similar to earlier results. ${ }^{6,10}$ An earlier study ${ }^{11}$ on gender differences regarding reasons for choices and types of drug use and their untoward effects including public views of women drug users revealed that the hitherto wide gap in the rate of drug use is gradually getting narrower (Table 2).

Among the respondents, the current PAS users constituted $211(39.96 \%)$. About $24 \%$ of siblings and $38.4 \%$ of friends/peers of current users were also users of PAS. It is an indication that, known users surrounded these current PAS users and they could have learnt the act from them. The rate of PAS use $(55.1 \%)$ in this study was higher than that obtained in a study ${ }^{8}$ but lower than that found in another research. ${ }^{12}$ The major contributors of influencing in PAS use were mostly friends/peers followed by siblings. This is comparable to other findings. ${ }^{13,14}$ These two groups were also the main ones who introduced the respondents to PAS use (Table 3).

Table 3. Demography of PAS users among the respondents, their family members and surroundings and introducers of the respondents to the use of PAS.

\begin{tabular}{|c|c|c|c|c|}
\hline \multicolumn{5}{|l|}{ Total respondents $(\mathrm{N}=528)$} \\
\hline Variables & Yes $(\%)$ & p-Value & Yes $(\%)$ & $\mathrm{p}$-Value \\
\hline Those that ever-used PAS & $291(55.1)$ & & - & \\
\hline Males & $195(36.9)$ & & - & \\
\hline Females & $96(18.2)$ & & - & \\
\hline Current PAS users & $211(39.96 \%)$ & & & \\
\hline $\begin{array}{l}\text { PAS users in members and surroundings of } \\
\text { users }(\mathrm{N}=211)\end{array}$ & $\begin{array}{l}\text { The family } \\
\text { current PAS users }\end{array}$ & & $\begin{array}{l}\text { Introducers } \\
\text { of PAS use }\end{array}$ & \\
\hline Father & $20(9.4)$ & $<0.000 *$ & $17(8.1)$ & $<0.000^{*}$ \\
\hline Mother & $8(3.8)$ & & $5(2.4)$ & \\
\hline Both parents & $15(7.1)$ & & $10(4.7)$ & \\
\hline Siblings & $51(24.2)$ & & $48(22.7)$ & \\
\hline Other family members & $23(10.9)$ & & $16(7.6)$ & \\
\hline Friends/Peers & $81(38.4)$ & & $105(49.8)$ & \\
\hline Family driver & $8(3.8)$ & & $5(2.4)$ & \\
\hline Family gateman & $5(2.4)$ & & $5(2.4)$ & \\
\hline
\end{tabular}

*= Statistically significant.

Alcohol was the commonest used PAS among the current users $(95.0 \%)$ and among the main population $(38.1 \%)$, which was higher than the findings in earlier works ${ }^{6,15}$, but lower than that obtained in a similar study. ${ }^{16}$ Alcohol has actually become a house hold name and is used in almost every nook and cranny of this country in almost every ceremony, which might have portrayed it to children as a common drink. Some other Nigerian studies $^{7,8}$, have also identified commonly used substances by both secondary school and university students to be alcohol, tobacco, marijuana, tranquilizers, kola nut and codeine in cough syrups which is in conformity with our findings (Table 4). 
Table 4. Prevalence of psychoactive substance use among respondents.

\begin{tabular}{|c|c|c|}
\hline $\begin{array}{l}\text { Psychoactive } \\
\text { substance }\end{array}$ & $\begin{array}{l}\text { Among the } \\
\text { current users } \\
(\mathrm{N}=211)\end{array}$ & $\begin{array}{l}\text { Among the main } \\
\text { population }(\mathrm{N}=528)\end{array}$ \\
\hline Variables & Frequency $(\%)$ & Frequency (\%) \\
\hline Tobacco & $61(28.9)$ & $61(11.6)$ \\
\hline Marijuana & $19(9.0)$ & $19(3.6)$ \\
\hline Tramadol & $78(37.0)$ & $78(14.8)$ \\
\hline Caffeine & $169(80.1)$ & $169(32.0)$ \\
\hline Heroin & $54(25.6)$ & $54(10.2)$ \\
\hline Codeine in syrup & $181(85.8)$ & $181(34.3)$ \\
\hline Cocaine & $34(16.1)$ & $34(6.4)$ \\
\hline Alcohol & $201(95.3)$ & $201(38.1)$ \\
\hline
\end{tabular}

Note: Multiple responses possible because some used more than one substance.
We recorded highly significant association between age and PAS use $(\mathrm{p}<0.000)$ which is in agreement with an earlier research ${ }^{17}$ but different from that of another ${ }^{18}$ which did not find any age association. Being male was found to be significantly associated with PAS use ( $\mathrm{p}=0.005)$, which is similar to some earlier works. ${ }^{18,10}$ Many males would likely try their hands-on hard things that may not normally appeal to females.

Our results found a strong association between PAS use and family members and friends/peers. A previous work ${ }^{13}$, identified social interaction between family and friends to be a significant factor for introduction to PAS use. An earlier study ${ }^{19}$ also found a positive relationship between both children and parents' alcohol use. Another significant association was that of parental marital status

Table 5. Association of demographic variables to psychoactive substance use $(\mathrm{N}=528)$.

\begin{tabular}{|c|c|c|c|c|c|}
\hline \multirow[b]{2}{*}{ Variables } & \multicolumn{2}{|c|}{ Substance use } & \multirow[b]{2}{*}{$\mathrm{X}^{2}$} & \multirow[b]{2}{*}{ Df } & \multirow[b]{2}{*}{ P-Value } \\
\hline & Yes $(\%)$ & No $(\%)$ & & & \\
\hline \multicolumn{6}{|l|}{ Age } \\
\hline$<15$ & $6(9.0)$ & $61(91.0)$ & 41.037 & 2 & $<0.000 *$ \\
\hline $15-18$ & $195(46.9)$ & $221(53.1)$ & & & \\
\hline$>18$ & $10(22.2)$ & $35(77.8)$ & & & \\
\hline \multicolumn{6}{|l|}{ Sex } \\
\hline Male & $145(44.8)$ & $179(55.2)$ & 8.023 & 1 & $0.005^{*}$ \\
\hline Female & $66(32.4)$ & $138(67.6)$ & & & \\
\hline \multicolumn{6}{|l|}{ Class level } \\
\hline SS1 & $38(37.6)$ & $63(62.4)$ & 2.099 & 2 & 0.350 \\
\hline SS2 & $104(43.3)$ & $136(52.5)$ & & & \\
\hline SS3 & $69(36.9)$ & $118(63.1)$ & & & \\
\hline \multicolumn{6}{|c|}{ Parent marital status } \\
\hline Single & $80(49.1)$ & $83(50.9)$ & 12.019 & 3 & $0.007 *$ \\
\hline Remained Married & $114(34.7)$ & $215(65.3)$ & & & \\
\hline Divorced/separated & $14(53.8)$ & $12(46.2)$ & & & \\
\hline Widowed & $3(30.0)$ & $7(70.0)$ & & & \\
\hline \multicolumn{6}{|l|}{ Family type } \\
\hline Monogamous & $160(37.3)$ & $269(62.7)$ & 7.841 & 2 & $0.020^{*}$ \\
\hline Polygamous & $46(53.5)$ & $40(46.5)$ & & & \\
\hline Single parent & $5(38.5)$ & $8(61.5)$ & & & \\
\hline \multicolumn{6}{|l|}{ Parental education } \\
\hline Illiterate/primary & $107(54.3)$ & $90(45.7)$ & 35.913 & 2 & $<0.000^{*}$ \\
\hline Secondary & $90(36)$ & $160(64)$ & & & \\
\hline Tertiary & $14(17.3)$ & $67(82.7)$ & & & \\
\hline \multicolumn{6}{|l|}{ Religion } \\
\hline Muslim & $67(40.1)$ & $100(59.9)$ & 3.031 & 2 & 0.220 \\
\hline Christian & $142(39.6)$ & $217(60.4)$ & & & \\
\hline Traditional & $2(100.0)$ & $0(0.0)$ & & & \\
\hline
\end{tabular}


Table 6. Knowledge of health consequences of psychoactive substance abuse ( $N=528)$.

\begin{tabular}{|c|c|c|c|c|c|}
\hline Class of PAS & Knowledge of Health Consequences of PAS Abuse & $\begin{array}{l}\text { True } \\
(\%)\end{array}$ & $\begin{array}{l}\text { False } \\
(\%)\end{array}$ & $\begin{array}{l}\text { Don't } \\
\text { know }(\%)\end{array}$ & p-value \\
\hline $\begin{array}{l}\text { Depressants (Alcohol, } \\
\text { Tranquilizer) }\end{array}$ & $\begin{array}{l}\text { Depression, anxiety disorders, psychiatric issues suicide risk. } \\
\text { Damage to brain, lung and liver resulting in dysfunction. }\end{array}$ & 78 & 52 & 398 & $<.000^{*}$ \\
\hline $\begin{array}{l}\text { Stimulants (Cocaine, } \\
\text { caffeine, Nicotine) }\end{array}$ & $\begin{array}{l}\text { Bronchial infections, lung cancer Cause convulsion, heart } \\
\text { malfunction, stroke, seizure and eventual death. }\end{array}$ & 45 & 31 & 452 & $<.000^{*}$ \\
\hline $\begin{array}{l}\text { Narcotics (Heroin, } \\
\text { codeine, tramadol) }\end{array}$ & $\begin{array}{l}\text { Mental deterioration, brain damage, result in hepatitis and } \\
\text { death in case of overuse. }\end{array}$ & 63 & 80 & 389 & $\begin{array}{l}< \\
0.000^{*}\end{array}$ \\
\hline Cannabis (Marijuana) & $\begin{array}{l}\text { Lowered blood pressure, and impairment of short-term } \\
\text { memory. Result in brain, heart and lung damage leading to } \\
\text { improper function. }\end{array}$ & 56 & 49 & 423 & $<.000^{*}$ \\
\hline
\end{tabular}

Average knowledge $=11.5 \%, *=$ Statistically significant

$(\mathrm{p}=0.007)$ where divorce or separation leads children to engage in illicit drug use. The adolescents need both parents most at this period of their growth for guidance and counseling in life matters but in the absence of these non-forth coming, they would definitely have to seek help elsewhere. We found a strong association between PAS use and a polygamous family $(\mathrm{p}=0.020)^{20}$ which makes it a risk factor in PAS abuse. The same thing goes when any of the family members engages in PAS use. Parental educational level was also highly associated with PAS use $(p<0.000)$. A former study ${ }^{6}$ stated that fathers with tertiary education would be able to expose relevant information to guide their children against PAS use. There was no association between religion and PAS use which is consistent with a previous finding ${ }^{20}$ (Table 5).

Our respondents' knowledge on health consequences of PAS use was significantly poor across board $(\mathrm{p}<0.000)$, and was also lower than that recorded by a similar study in Nigeria ${ }^{10}$ (Table 6).

A study of United States of America showed that, negative effects of PAS use which include mood and anxiety disorders develop independently apart from intoxication and withdrawal and they are responsible for main psychiatric disorders seen in the country. ${ }^{21}$ It has also been ascertained that PAS use by adolescents could lead to some serious health issues such as acute respiratory failure, bronchial infections, lung cancer, heart attacks, mental health complications or death. ${ }^{5,10}$

\section{CONCLUSION}

The effects of the consequences of PAS use on the adolescents' health translate to the family, the community as well as to the nation. There is need for continuous health educational intervention to boost the populace's knowledge of health consequences of PAS use especially among the adolescents. We should all see PAS use as a common enemy and join hands to fight it.

\section{ACKNOWLEDGEMENT}

The authors sincerely appreciate the respondents in this study as well as the school Principals who granted us permission to carry out the study.

\section{Conflicts of interest}

The authors declare no conflicts of interest

\section{REFERENCES}

1. American Psychiatric Association DSM-IV. 1994. Diagnostic and Statistical Manual on Mental Disorders. American Psychiatric Association. Washington DC. pp. 175184.

2. United Nations Office on Drugs and Crime. 2014: World Drug Report obtained from www.unodc.org. Accessed on 15/9/2019.

3. Global Perspective on Tobacco in America. 2014. 701 4th Street, NW Washington, DC 20001. www.ash.org p. 202659-4310. Accessed on 15/9/2019.

4. Kayoni, M., Gishoma, D. and Ndahindwa, V. 2015. Prevalence of psychoactive substance use among youth in Rwanda. DOI 10.1186/s13104-015-1148-2. 
5. Deressa, W. and Azazh, A. 2011. Substances use and its predictors among undergraduate medical students of Addis Ababa University in Ethiopia. BMC. Pub. Health. 11, 660.

6. Idowu, A., Aremu, A.O., Olumide, A. and Ogunlaja, A.O. 2018. Substance abuse among students in selected secondary schools of an urban community of Oyo-state, South West Nigeria: implication for policy action. Afri. Health. Sci. 18, 776-785. https://dx.doi.org/10.4314/ahs.v18i3.36.

7. Abasiubong, F., Udobang, J.A., Idung, A.U., Udoh, S.B and Jombo, H.E. 2014. A Comparative study of pattern of substance use in two Nigerian cities located in the Southern and Northern Nigeria. An. Int. Mult. J. Ethiopia. 8, Serial No. 33, 52-67.

8. Atoyebi, O.A. and Atoyebi, O.E. 2013. Pattern of substance abuse among senior secondary school students in a southwestern Nigeria city. Intl. Review Soc. Hum. 4, 54-65. www.irssh.com.

9. Gureje, O., Degenhardt, L., Olley, B., Uwakwe, R., Udofia, O., Wakil, A., Adeyemi, O., Bohnert, K.M. and Anthony, J.C. 2007. A descriptive epidemiology of substance use and substance use disorders in Nigeria during the early $21 \mathrm{st}$ century. Drug. Alcohol. Depend. 91, 1-9. doi: 10.1016/j.drugalcdep.2007.04.010. [PubMed:17570618].

10. Oshodi, O.Y., Aina, O.F. and Onajole, A.T. 2010. Substance use among secondary school students in an urban setting in Nigeria: prevalence and associated factors. Afr. J. Psy. 13, 24-38.

11. Greenfield, S,F., Back, S.E., Lawson, K. and Kathleen, T.B. 2010. Substance abuse in women. Psych. Clin. North America. 33, 339-355.

12. Lawoyin, T.O., Ajumobi O.O., Abdul M.M., Abdul Malik, J.O., Adegoke, D.A. and Adebiyi, O.A. 2005. Drug use among senior secondary school students in rural Nigeria. Afr. J. Med. Sci. 34, 355-339.

13. Bassi, A.P., Idoko, L., Ogundeko, T.O., Ramyil, M.S.C., Abisoye-Ogunniyan, A., Ogbole, E.A., Thilza, S.A., SuleUredo'ojo, Ante, E., Bassey, Baba, A., Ishaku, Chimbuoyim. and Iheanacho, N. 2017. Substance abuse and its prevalence among secondary school adolescents in Kagoro, Kaduna state, Nigeria. World. J. Res. Rev. (WJRR). 5, 11-16.
14. Obiechina, G.O and Isiguzo, B.C. 2016. Curbing the Menace of Drug Use Among Secondary School Students in Nigeria. Eur. J. Res. Ref. Edu. Sci. 4, 53-64.

15. Alex-Hart B.A., Opara P.I. and Okagua J. 2015. Prevalence of alcohol consumption among secondary school students in Port Harcourt, southern Nigeria. Niger. J. Paed. 42, 39-45.

16. Dechenla, T., Ranabir, P. and Aparajita, D. 2010. Substance use among the adolescent high school students in India: a survey of knowledge, attitude, and opinion. 2, 137-140.

17. Chinawa, J.M., Manyike, P.C., Obu, H.A., Odetunde, O.I., Uwaezuoke, S., Ikefuna, A.N., Aronu, A.E. and Chinawa, A.T. 2015. Substance use among medical students attending two Nigerian universities. Int. Neuropsych. Dis. 3, 27-34. DOI:10.9734/INDJ/2015/12795.

18. Akanni, O.O. and Adayonfo, E.O. 2015. Correlates of psychoactive substance use among Nigerian adolescents. Sahel. Med. J. 18, 192-199.

19. Cleveland, M.J., Frederick, X.G., Meg, G., Elizabeth, A.P. and Gene, H.B. 2005. The impact of parenting on risk cognitions and risk behavior: a study of mediation and moderation in a panel of African-American adolescents. Child. Dev. 76, 900-916.

20. Fatoye, F.O. and Morakinyo, O. 2002. Substance use amongst secondary school students in rural and urban communities in south western Nigeria. East. Afr. Med. J. 79, 299-305.

21. Grant, B.F., Stinson, F.S., Dawson, D.A., Patricia, C., Dufour, M.C., Compton. W., Pickering, R.P. and Kaplan, K. 2004. Prevalence and co-occurrence of substance use disorders and independent mood and anxiety disorders: results from the national epidemiologic survey on alcohol and related conditions. Arch. Gen. Psy. 61, 807-816. 